\title{
District heating system design for a university campus
}

\author{
Nurdan Yıldırım, Macit Toksoy, Gülden Gökçen* \\ Izmir Institute of Technology, Faculty of Engineering, Department of Mechanical Engineering, \\ Gülbahçe köyü, 35430 Urla-İzmir, Turkey
}

Received 19 September 2005; received in revised form 8 January 2006; accepted 11 January 2006

\begin{abstract}
İzmir Institute of Technology campus is in use since 2000 and still under development. At present, heating is provided by individual fuel boilers. On the other hand, the campus has a geothermal resource in its borders with a temperature of $33{ }^{\circ} \mathrm{C}$. Because of this low geothermal fluid temperature; heat pump district heating system is considered for the campus. As an alternative, fuel boiler district heating system is studied. Each heating system is simulated using hourly outdoor temperature data. For the simulations, a control system with constant flow rate and variable return water temperature is used and the main control parameter is the indoor temperature. Various heating regime alternatives have been studied for heat pump district heating system for the various condenser outlet temperature and geothermal fluid flow rate, and two of these alternatives are given in this study. Furthermore, economic analysis has also been done for each heating system alternative based on investment and operational costs. Results indicate that heat pump district heating system has the highest investment but lowest operational cost.

The alternatives are evaluated according to internal rate of return method, which shows the profit of the investment and resulted that, the heat pump district heating system has minimum 3.02\% profit comparing with the fuel boiler district heating system at the end of the 20 -year period. (C) 2006 Elsevier B.V. All rights reserved.
\end{abstract}

Keywords: Geothermal energy; District heating system; Heat pump; Turkey

\section{Introduction}

A district heating system is composed of many elements, building a chain from the heat source to the heated buildings. The sole purpose of a district heating system is to supply adequate heat to its customers. The consumer uses the heat to maintain indoor temperature at a reasonably constant level and counter for building heat loss to the surroundings. Most district heating systems use conventional fuel (oil, natural gas or coal) as the heat source. In some areas geothermal heat is used as the district heating source and experience has shown that low temperature geothermal fluid $\left(<120^{\circ} \mathrm{C}\right)$ is well suited for this purpose. The heat distribution in district heating systems is carried out by the use of either hot water or steam through a closed loop network, where the hot water or steam is piped to each consumer in the supply network, cooled down by the heat consumer, piped back to the heat centre and re-heated [1].

İmir Institute of Technology campus, founded in 1992, is heated by individual fuel boilers. On the other hand, the campus has a geothermal resource with a temperature of $33{ }^{\circ} \mathrm{C}$.

\footnotetext{
* Corresponding author. Tel.: +90 232 7507805; fax: +90 2327507890.

E-mail address: guldengokcen@iyte.edu.tr (G. Gökçen).
}

Therefore in this study, design of a geothermal district heating system is studied and compared with fuel boiler heating system.

The methods by which heat is extracted from geothermal fluid depend strongly on temperature of the fluid and nature of the heating application. There are two basic methods of heat extraction, which are used in heating applications: Direct heat exchange and heat pump. The use of heat pumps is often considered when the fluid temperature is too low $\left(<40{ }^{\circ} \mathrm{C}\right)$ for heat transfer to occur by direct heat exchange [2].

Because of the low temperature of the geothermal resource in the campus, for a geothermal district heating system design, heat pumps are considered suitable. To be able to compare the new design using a renewable energy resource, a fossil fuel district heating system which uses fuel oil is also investigated. For both heating systems (geothermal heat pump and fuel boiler), three heating scenarios are considered depending on the heating period. Indoor temperature of the buildings is the main control parameter of the heating simulations. Mathematical models were derived; the programs using Matlab [3] and EES [4] have been written and run using hourly weather data. The investment and operational costs of the heating system alternatives are calculated. Then, the investment costs are analysed according to internal rate of return method $[5,6]$. 


\begin{tabular}{ll} 
Nomenclature \\
COP & coefficient of performance of heat pump \\
$C_{\mathrm{p}}$ & specific heat capacity of the fluid $\left(\mathrm{kJ} / \mathrm{kg}{ }^{\circ} \mathrm{C}\right)$ \\
$\dot{m}$ & flow rate of the fluid $(\mathrm{kg} / \mathrm{s})$ \\
$M$ & water mass $(\mathrm{kg})$ \\
$n_{\mathrm{hp}}$ & number of operating heat pump unit in the heat- \\
& ing system \\
$N_{\mathrm{hp}}$ & number of existing heat pump unit in the heating \\
$\dot{Q}$ & system \\
$t$ & heat transfer rate $(\mathrm{kW})$ \\
$T$ & time $(\mathrm{s})$ \\
$\dot{W}$ & temperature $\left({ }^{\circ} \mathrm{C}\right)$ \\
nreek heat pump inlet power $(\mathrm{kW})$ \\
$\Delta t$ & time step (s) \\
Subscripts \\
0 & reference condition \\
$\mathrm{b}$ & boiler outlet \\
boiler & boiler \\
car & carnot \\
cond & condenser \\
eva & evaporator \\
$\mathrm{g}$ & geothermal fluid \\
$\mathrm{g} 0$ & maximum geothermal fluid \\
in & evaporator water inlet \\
out & evaporator water outlet \\
$\mathrm{p}$ & previous \\
$\mathrm{r}$ & return \\
$\mathrm{s}$ & supply \\
sh & condenser outlet \\
$\mathrm{w}$ & water between evaporator and heat exchanger \\
Superscripts \\
$(\mathrm{dot})$ & quantity per unit time \\
& \\
\hline
\end{tabular}

While conventional heating systems are designed for peak load, geothermal district heating systems are designed by using a heat load factor around 0.6 [7]. Heat load factor for İzmir City is calculated as 0.67 for $0{ }^{\circ} \mathrm{C}$ outdoor and $20^{\circ} \mathrm{C}$ balance temperature [5].

\section{Introduction to İzmir Institute of Technology campus}

The campus, which has a total area of 3500 ha, is located in Urla, about $40 \mathrm{~km}$ west of İzmir with a highway connection.

The construction of the campus buildings was started in 1994. The number of the buildings has currently reached to 15 with a floor area of $50,730 \mathrm{~m}^{2}$ and the campus is still developing. The total heat load of the existing buildings is about $3662 \mathrm{~kW}$. When the development completed total heat load of the campus will reach to $11,207 \mathrm{~kW}$ [5].

Individual HVAC (heating, ventilation and air conditioning) systems are employed at each building group. On the

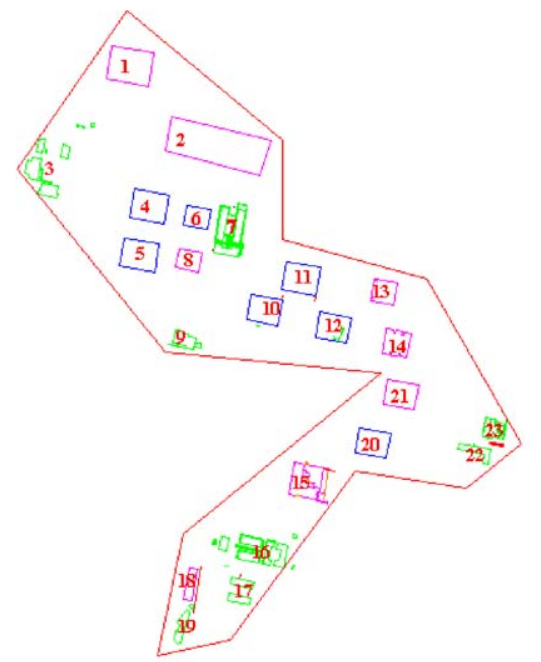

1: Staff houses

2: Dormitories

3: Architecture Faculty

4: Buildings A

5: Buildings $B$

6: Buildings $\mathrm{C}$

7: Science Faculty

9: Cafeteria

10: Buildings $E$

11: Buildings $F$

12: Research \& Development. Centre
8: Buildings D
13: Sport Centre

14: Medical Centre

15: ChemicalEngineering

16: Engineering Faculty

17: Mechanical Engineering

18: Mechatronic Building

19: Incubator Building

20: Buildings G

21: Library

22: Presidency of Depart. Building

23: Rectorship Building
Fig. 1. Location of the buildings in the campus [5].

other hand, a geothermal resource exists in the campus. Exploration studies in the field started in 1995. In 2002, five gradient wells were drilled and one of which is assigned as production well having a $33{ }^{\circ} \mathrm{C}$ temperature and $30 \mathrm{~kg} / \mathrm{s}$ flow rate.

A thermal load inventory, which is initially required for design of a district heating system, is done for İzmir Institute of Technology campus. Thermal load density is an important indication on the decision whether if the district heating system should be installed or not. The buildings in the campus are distributed in an area as large as 71.3 ha as it is shown in Fig. 1. Using the area and total heat load, thermal load density of the campus is calculated as $0.16 \mathrm{MW} / \mathrm{ha}$.

The criteria for district heating system favourability based on thermal load density are given in Table 1. According to

Table 1

Favourability based on thermal load density [1]

\begin{tabular}{lll}
\hline Type of land-use & $\begin{array}{l}\text { Thermal load } \\
\text { density (MW/ha) }\end{array}$ & $\begin{array}{l}\text { Desirability for } \\
\text { district energy }\end{array}$ \\
\hline $\begin{array}{l}\text { Downtown; high rises } \\
\text { Downtown; multi-storied }\end{array}$ & $\begin{array}{l}\text { Greater than } 0.70 \\
\text { City core; commercial }\end{array}$ & $\begin{array}{l}\text { Very favourable } \\
\text { buildings and multi-family } \\
\text { apartments }\end{array}$ \\
$\begin{array}{l}\text { Two-family residential } \\
\text { Single-family residential }\end{array}$ & $0.20-0.51$ & $\begin{array}{l}\text { Favourable } \\
\text { Possible }\end{array}$ \\
\hline
\end{tabular}




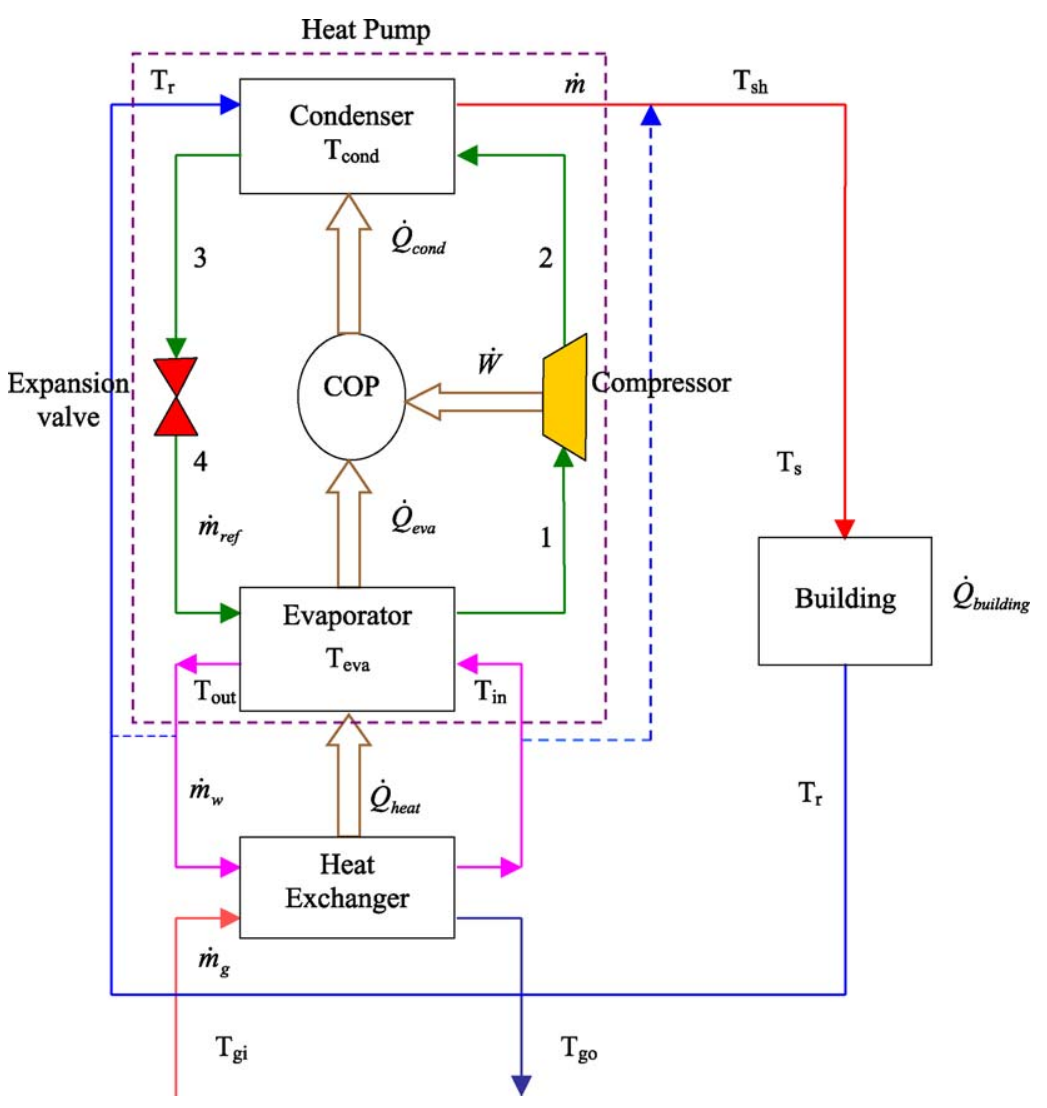

Fig. 2. Considered district heating system with heat pump.

Table 1, favourability of a district heating system for İzmir Institute of Technology campus is questionable, because of the widespread distribution of the buildings. On the other hand, if cooling of the buildings is also considered, the favourability ratio increases depending on the total heat load. Considering the future development and cooling requirements, campus district heating system is appeared to be possible [5].

\subsection{Heating system model}

In the study, heat pump and fuel boiler heating systems are simulated.

\subsubsection{Heat pump model}

Heat pumps are not single elements like primary heat exchangers or back-up boilers. The evaporators and condensers are located in different parts of the system and also by-pass connections of various types are possible. Consequently a wide variety of different layouts are possible in geothermal schemes all of which can, in general, perform differently.

If attention is focused on the way in which the heat pump supplies heat in any scheme, then two basic classes of configuration can be identified.

- The heat pump assists the primary heat exchanger, supplying additional heat from the geothermal fluid, which is called the heat pump assisted (HPA) approach.
- The heat pump dominates the geothermal supply and no heat is transferred if the heat pump is not operating, which is called the heat pump only (HPO) approach.

As a general rule if,

- $T_{\mathrm{gi}}>40^{\circ} \mathrm{C}$ 'heat pump assisted',

- $T_{\mathrm{gi}}<40{ }^{\circ} \mathrm{C}$ 'heat pump only' layouts are recommended [2].

Heat pump only type heat pump is considered for the campus district heating system since existing geothermal fluid temperature is $33^{\circ} \mathrm{C}$. Because of the corrosion effects of the geothermal fluid, a heat exchanger is also considered. Geothermal fluid passes from the heat exchanger rather than evaporator (Fig. 2).

For İzmir Institute of Technology campus district heating system, four separate heat pump units of the same capacity are considered because of the improved performance, reliability and operational flexibility. Each heat pump, which is employed with one heat exchanger, is fed by each production well and heat pumps are operated depending on the outdoor temperature.

- If outdoor temperature is between 0 and $5{ }^{\circ} \mathrm{C}$, all heat pumps,

- If outdoor temperature is between 5 and $10^{\circ} \mathrm{C}$, three heat pumps,

- If outdoor temperature is between 10 and $13{ }^{\circ} \mathrm{C}$, two heat pumps, 
- If outdoor temperature is between 13 and $18{ }^{\circ} \mathrm{C}$, only one heat pump will be operated.

The heat pump units are considered to be installed in parallel. Thus, there is a relation between geothermal flow rate and the number of heat pump units in operation. If total number of heat pump units is $N_{\mathrm{hp}}$, the number of heat pump units in operation at any time is $n_{\mathrm{hp}}$ and maximum flow rate of the geothermal fluid is $\dot{m}_{\mathrm{g} 0}$, geothermal flow rate at any time can be calculated as;

$\dot{m}_{\mathrm{g}}=\frac{n_{\mathrm{hp}}}{N_{\mathrm{hp}}} \dot{m}_{g 0}$

Campus loop is operated for constant flow rate, variable supply temperature principle. Similarly, supply temperature changes with the number of the heat pump units in operation. If heat pump is completely shut down, condenser outlet temperature equals to return temperature at previous step for that heat pump. Thus, supply temperature of the campus loop system can be calculated as;

$T_{\mathrm{s}}(i)=\frac{T_{\mathrm{sh}}(i) n_{\mathrm{hp}}+T_{\mathrm{r}}(i-1)\left(N_{\mathrm{hp}}-n_{\mathrm{hp}}\right)}{N_{\mathrm{hp}}}$

Here, $T_{\text {sh }}$ represents condenser outlet temperature, when heat pump is operating and $(i-1)$ represents previous step.

2.1.1.1. Simplification of heat pump capacity calculation. The Carnot efficiency of the heat pump can be defined as the ratio of the heat released to work input.

$\mathrm{COP}_{\text {car }}=\frac{T_{\text {cond }}}{T_{\text {cond }}-T_{\text {eva }}}$

$\mathrm{COP}=\frac{\dot{Q}_{\text {cond }}}{\dot{W}}=\frac{\dot{Q}_{\text {cond }}}{\dot{Q}_{\text {cond }}-\dot{Q}_{\text {eva }}}$

It is also often assumed that the thermal and mechanical losses in the cycle reduce the performance further to about $50 \%$ of the theoretical value. The COP becomes [5];

$\mathrm{COP}=0.5 \mathrm{COP}_{\mathrm{car}}$

According to Fig. 2 the heat pump heat flows can be written as;

$\dot{Q}_{\text {con }}=\dot{m} C_{\mathrm{p}}\left(T_{\mathrm{sh}}-T_{\mathrm{r}}\right)$

$\dot{Q}_{\text {eva }}=\dot{m}_{\mathrm{w}} C_{\mathrm{p}}\left(T_{\text {in }}-T_{\text {out }}\right)$

\subsubsection{Boiler model}

The boiler is considered as a source with constant heat added to the water flowing into it. The outlet temperature from the boiler $T_{\mathrm{b}}$ is calculated according to the following relation, which is based on the principle of energy conservation of the boiler. $\frac{\mathrm{d} T_{\mathrm{b}}}{\mathrm{d} t}=\frac{\dot{Q}_{\mathrm{boiler}}-\dot{m} C_{\mathrm{p}}\left(T_{\mathrm{b}}-T_{\mathrm{r}}\right)}{M_{\mathrm{boiler}} C_{\mathrm{p}}}$

In this work, supply water temperature is assumed equal to boiler outlet temperature. Integrating Eq. (8), over a time step of $\Delta t$ yields

$T_{\mathrm{b}}(t)=\frac{\dot{Q}_{\text {boiler }}-\dot{m} C_{\mathrm{p}} T_{\mathrm{r}}-\dot{Q}_{\mathrm{r}}}{\dot{m} C_{\mathrm{p}}}$

where

$\dot{Q}_{\mathrm{r}}=\left[\dot{Q}_{\text {boiler }}+\dot{m} C_{\mathrm{p}}\left(T_{\mathrm{r}}-T_{\mathrm{b}(\mathrm{p})}\right)\right] \exp \left(-\frac{\Delta t \dot{m}}{M_{\text {boiler }}}\right)$

$T_{\mathrm{b}(\mathrm{p})}$ is the boiler water temperature at the previous time step [8].

For fuel boiler district heating system, piping network and location of the heat centre are chosen the same as heat pump district heating system. Five boilers with a capacity of $2326 \mathrm{~kW} /$ each are considered for fuel boiler district heating system [5].

\section{Design}

\subsection{Heat pump district heating system}

The parameters to be determined for the heat pump heating system (Fig. 2) design are as follows;

- Condenser outlet temperature $\left(T_{\mathrm{sh}}\right)$,

- Geothermal fluid flow rate $\left(\dot{m}_{\mathrm{g}}\right)$,

- Coefficient of the performance (COP) of the heat pump.

\subsubsection{Condenser outlet temperature}

It is desirable to have a minimum temperature difference between condenser inlet and outlet to obtain high COP values for heat pumps. COP values depending on geothermal flow rate are plotted in Fig. 3 for various condenser outlet temperatures $\left(40-55{ }^{\circ} \mathrm{C}\right)$ at $35^{\circ} \mathrm{C}$ condenser inlet temperature and $33{ }^{\circ} \mathrm{C}$ geothermal fluid temperature $\left(T_{\mathrm{gi}}\right)$. As it can be seen from Fig. 3, COP value increases with increasing geothermal fluid

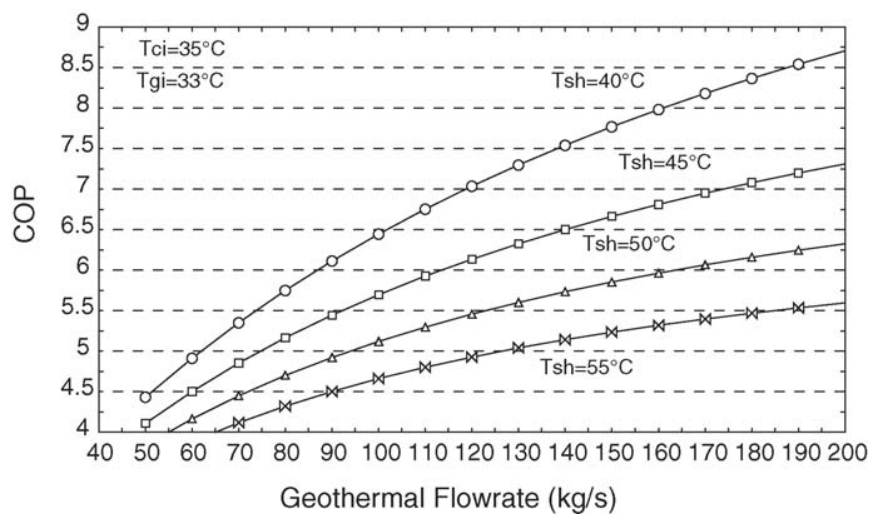

Fig. 3. Relationship between geothermal flow rate and COP. 


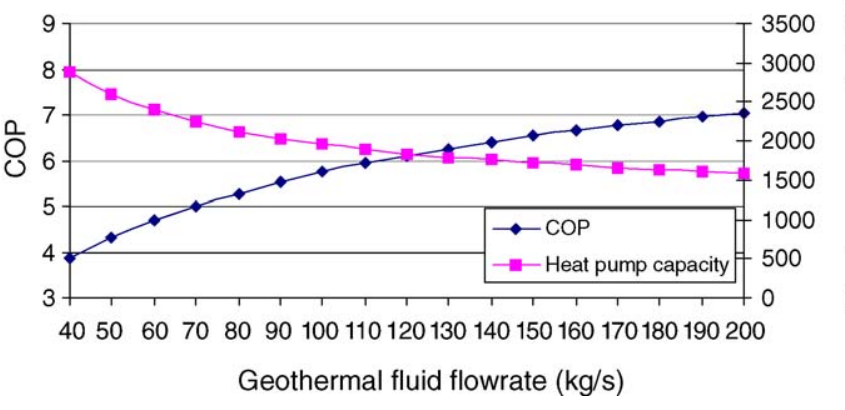

Fig. 4. Relationship between geothermal fluid flow rate, COP and compressor work for $45^{\circ} \mathrm{C}$ condenser outlet temperature.

flow rate and decreasing condenser outlet temperature. But, there is a trade-off between condenser outlet temperature and economy of the system. Low condenser outlet temperature causes reduction in heating equipment performance, increase in flow rate and network pipe diameter. But large heat pump units have high COP values with small temperature difference between supply (condenser outlet) and return (condenser inlet) temperature. In manufacturer's catalogues COP value is given as 5-8 for large heat pump units. An example for $45^{\circ} \mathrm{C}$ supply and $35^{\circ} \mathrm{C}$ return temperature $\left(\Delta T=10^{\circ} \mathrm{C}\right), \mathrm{COP}$ is around 6 for large heat pump capacities [9]. On the other hand for $55^{\circ} \mathrm{C}$ supply and $35^{\circ} \mathrm{C}$ return temperature $\left(\Delta T=20^{\circ} \mathrm{C}\right), \mathrm{COP}$ is around 4 and capacity of the heat pumps is small. Thus, the number of heat pump units is increased for large temperature differences. This also causes an increase in investment and operational costs. Therefore, there is a trade-off between COP and condenser outlet temperature. For a COP around $6,45^{\circ} \mathrm{C}$ condenser outlet temperature gives the best result.

\subsubsection{Geothermal fluid flow rate}

For a given condenser outlet temperature, relationship among geothermal fluid flow rate, COP and heat pump capacity is shown in Fig. 4.

For a COP of 6 and $45^{\circ} \mathrm{C}$ condenser outlet temperature, Fig. 4 gives a geothermal flow rate of $120 \mathrm{~kg} / \mathrm{s}$ and a heat pump capacity of $1877 \mathrm{~kW}$. Required number of the production wells is 4 to meet the $120 \mathrm{~kg} / \mathrm{s}$ geothermal flow rate requirement.

Depending on $45^{\circ} \mathrm{C}$ condenser outlet temperature, heating system is selected to have $45^{\circ} \mathrm{C}$ supply/35 ${ }^{\circ} \mathrm{C}$ return temperature. Consequently, flow rate in the campus loop, is calculated as $179.4 \mathrm{~kg} / \mathrm{s}$ with Eq. (2) based on heat load factor of 0.67 .

\subsection{Fuel boiler district heating system}

Conventional heating systems are designed for peak load. Thus, the total heat load of the system is taken as $11,207 \mathrm{~kW}$ and heating equipment is designed for supply and return temperatures of 90 and $70{ }^{\circ} \mathrm{C}$, respectively.

\subsubsection{Determining the best heating regime}

The current heating system of the campus is individual boilers, which are operated manually by technicians, employed at each building group. Each technician turns on or off the system and changes the boiler set temperature according to his/ her experience. Therefore, the buildings in each group are heated in a different way. Obtaining the required heat depends on the running time of the boiler and boiler set temperature. Fuel consumption of the boiler changes drastically depending on the boiler set temperatures. Thus, to obtain the best heating regime and boiler set temperature as a function of outdoor temperature, four alternatives are simulated. For each alternative, simulation results are given in Table 2 [5].

\section{Results}

\subsection{Heat pump district heating system}

- Heating system runs $1055 \mathrm{~h}$ for determined heating period.

- Variations of the heat pump and heat exchanger characteristics for heating period are shown in Fig. 5.

- Variations of geothermal flow rate requirements for heating period are calculated using Eq. (1). Variable flow rate of geothermal fluid can be managed using storage tank or variable speed circulation pumps. The peak flow rate is $120 \mathrm{~kg} / \mathrm{s}$ and annual flow rate requirement is $281,124 \mathrm{t}$. The average necessary flow rate is calculated as $74 \mathrm{~kg} / \mathrm{s}$.

- Geothermal fluid return temperature varies between 10 and $21{ }^{\circ} \mathrm{C}$.

- Variations of the supply and return water temperatures during the heating season can be viewed in Fig. 6 .

Table 2

Results of the simulations of fuel boiler district heating system [5]

\begin{tabular}{|c|c|c|c|c|}
\hline Alternative no. & $\begin{array}{l}\text { Boiler set } \\
\text { temperature }\left({ }^{\circ} \mathrm{C}\right)\end{array}$ & $\begin{array}{l}\text { Average indoor temperature } \\
\text { during working hours }\left({ }^{\circ} \mathrm{C}\right)\end{array}$ & $\begin{array}{l}\text { Fuel-oil consumption of } \\
\text { the boiler heating system }(\mathrm{kg})\end{array}$ & $\begin{array}{l}\text { Cost of the fuel } \\
\text { consumption (US\$) }\end{array}$ \\
\hline 1 & $T_{\mathrm{b} \_}$set $=80$ & 24.3 & 899540 & 476756 \\
\hline 2 & $T_{\mathrm{b} \_}$set $=60$ & 21.7 & 684048 & 362545 \\
\hline 3 & 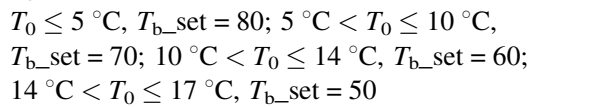 & 20.7 & 662886 & 351330 \\
\hline 4 & 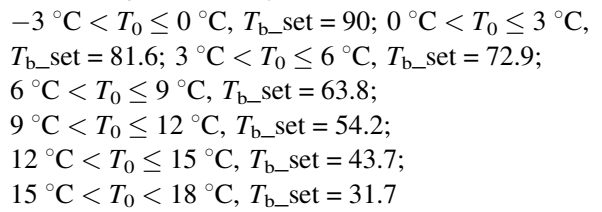 & 20.1 & 618500 & 327780 \\
\hline
\end{tabular}



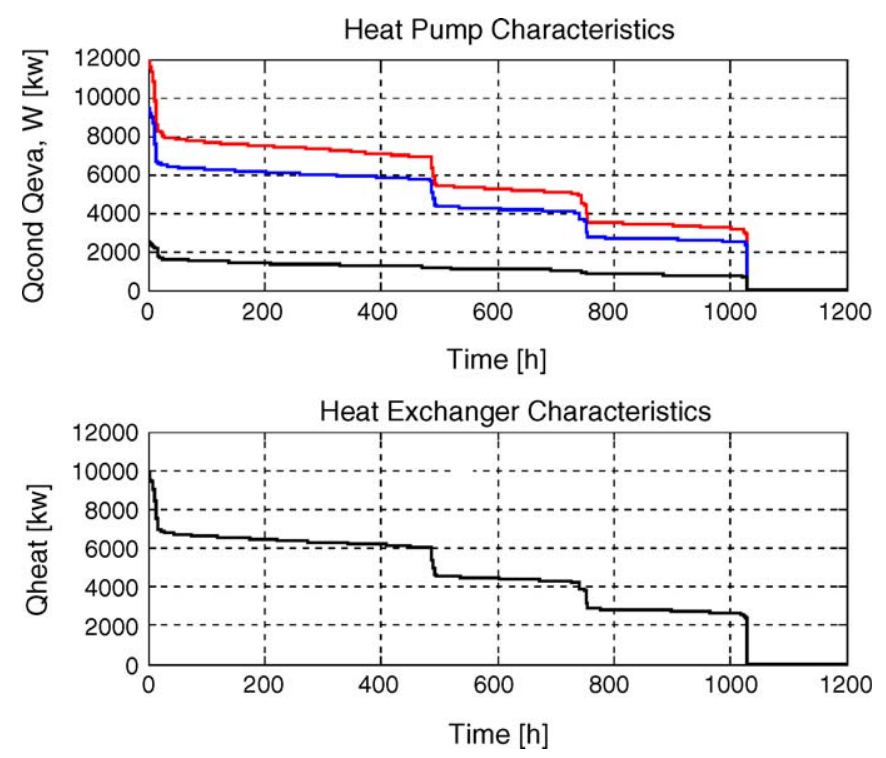

Fig. 5. Variations of heat pump and heat exchanger characteristics according to simulation program.

- Heating equipment heat supply and building heat loss duration curves are shown in Fig. 7. As it is clearly seen that heating equipment meet the required duty most of the time except some points, which are shown in the circles in Fig. 7.

- For steady state approach, indoor temperature is assumed constant, $20{ }^{\circ} \mathrm{C}$, at balance temperature. But for dynamic approach indoor temperature is calculated. In Fig. 8, variations of indoor temperature and outdoor temperature during the operating period are shown. Fig. 8 indicates that the indoor temperature is mostly over $20{ }^{\circ} \mathrm{C}$, but some times, which are shown in the rectangular; it is below $20^{\circ} \mathrm{C}$. At those times, outdoor temperature drops below $5{ }^{\circ} \mathrm{C}$ and since the system is designed for $67 \%$ of the peak load, heat supply from the heating equipment is not enough to maintain the set indoor temperature.
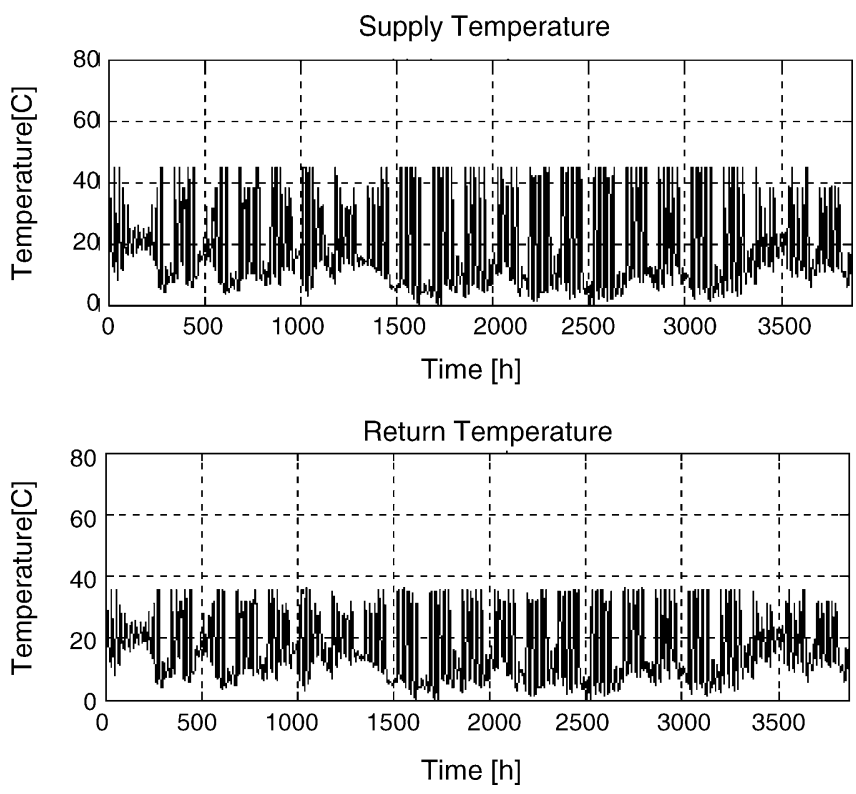

Fig. 6. Variations of supply and return water temperatures.
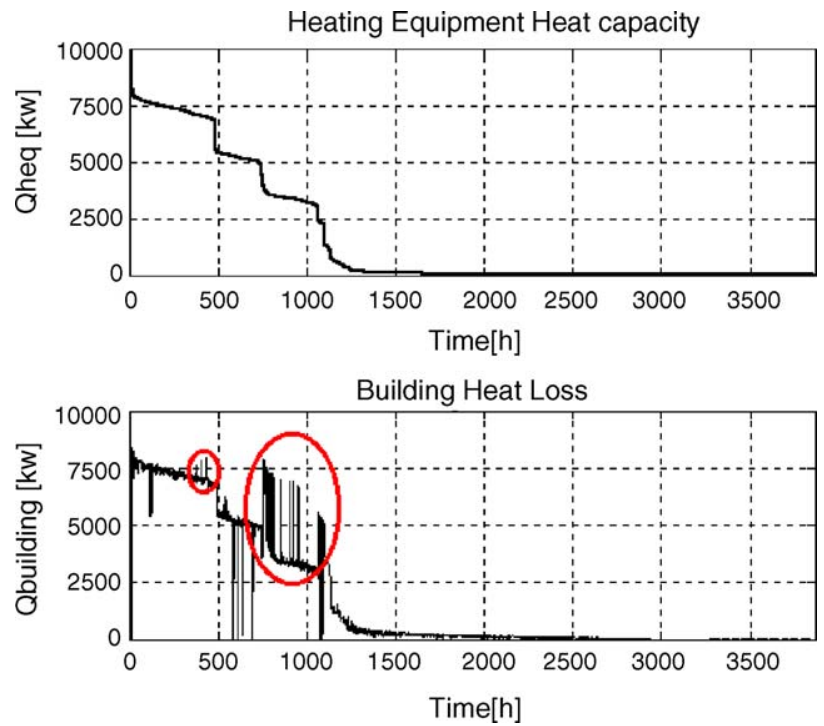

Fig. 7. Duration curves of heating equipment heat supply and building heat loss.

\subsection{Fuel boiler district heating system}

Indoor temperature variations of the alternatives are plotted in Fig. 9.

Table 2 and Fig. 9 indicate that Alternative 4, which uses a boiler set temperature recommended by Dağsöz [10], is the best one with least fuel consumption and best indoor temperature around $20^{\circ} \mathrm{C}$.

\subsection{Economical analysis}

Three heating scenarios, given in Table 3 , are evaluated based on their investment and operational costs.

Annual heating requirements are calculated for each scenario according to degree-hour method as 5,129,892,
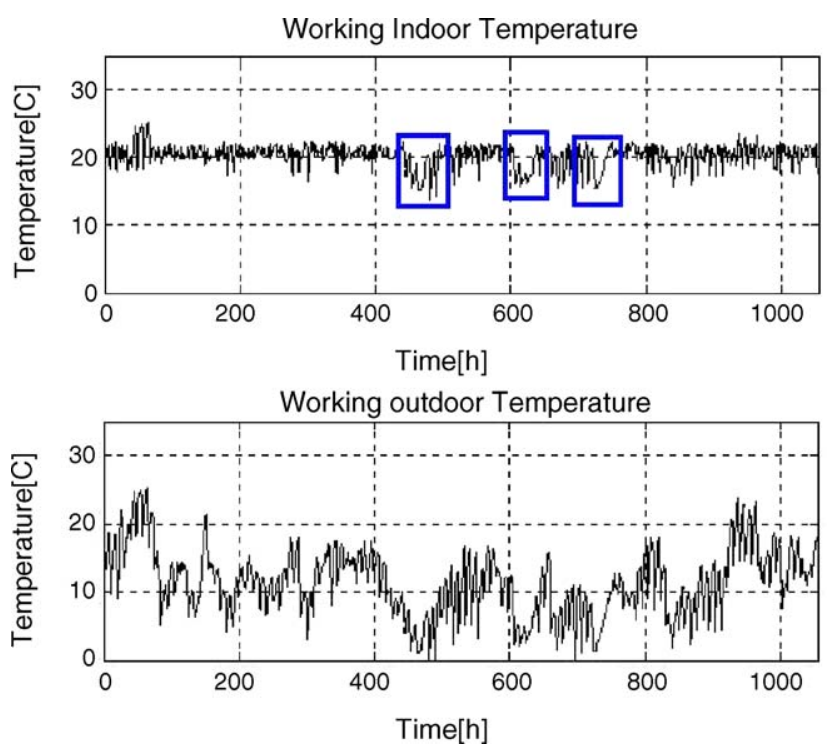

Fig. 8. Variations of indoor and outdoor temperature during the working period. 

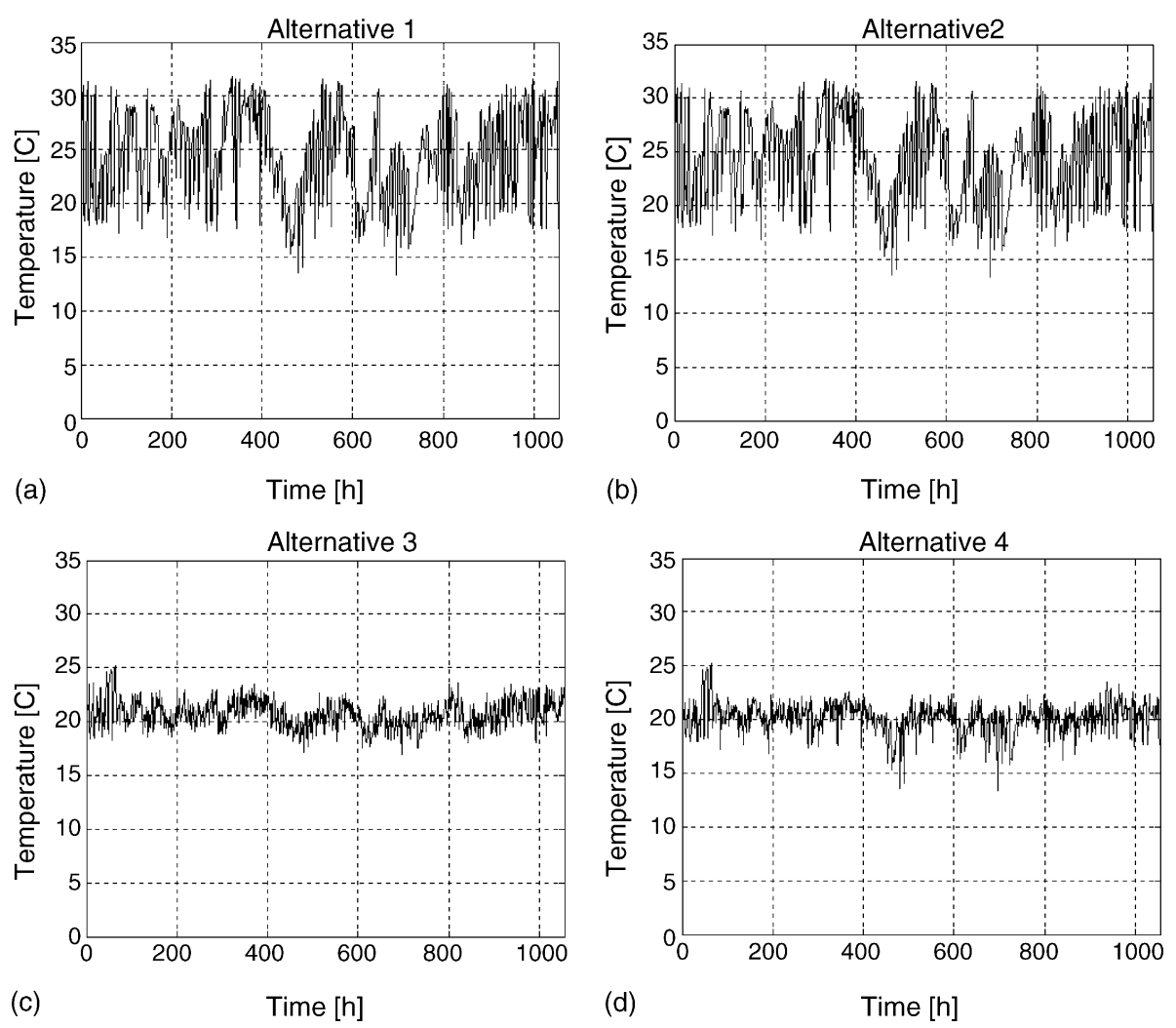

Fig. 9. Variation of indoor temperatures of alternatives of fuel boiler district heating system.

6,897,293 and 9,612,556 kWh, respectively. Depending on the annual heating requirements of the buildings, annual operational costs are calculated. Total investment and operational cost of the heating system alternatives are given in Table 4.

Table 4 indicates that investment cost of heat pump district heating system is approximately three times higher than fuel boiler district heating system. The largest portions of investment cost for heat pump and fuel boiler district heating system are heat pump units and control systems, respectively.

On contrary Table 4 exhibits that operational cost of heat pump district heating system is three times lower than fuel boiler district heating system.

Table 3

Heating scenarios for the buildings in the campus

\begin{tabular}{|c|c|}
\hline Scenario no. & Explanation \\
\hline 1 & $\begin{array}{l}\text { All buildings in the campus are heated } \\
\text { between } 8.00 \text { a.m. and } 17.00 \text { p.m. during the week }\end{array}$ \\
\hline 2 & $\begin{array}{l}\text { All buildings in the campus are heated } \\
\text { between } 8.00 \text { a.m. and } 20.00 \text { p.m. during the week }\end{array}$ \\
\hline 3 & $\begin{array}{l}\text { Office buildings in the campus are heated } \\
\text { between } 8.00 \text { a.m. and } 20.00 \text { p.m. during the week } \\
\text { Sport Centre, Medical Centre and Library are } \\
\text { heated between } 8.00 \text { a.m. and } 22.00 \text { p.m. during all week } \\
\text { Sport Centre, Medical Centre and Library are heated } \\
\text { between } 9.00 \text { a.m. and } 15.00 \text { p.m. during weekend } \\
\text { Staff houses and dormitories are heated } 24 \mathrm{~h} \text { for everyday }\end{array}$ \\
\hline
\end{tabular}

Operational cost of the heat pump and fuel boiler district heating system is categorised into electricity, fuel oil, personnel, water, inhibitor, other chemicals and maintenance (Table 5). Table 5 exhibits that the electricity consumption cost of the heat pumps, circulation and well pumps constitutes about $84 \%$ in total operational cost of the heat pump district heating system. For fuel boiler district heating system, fuel oil cost has the largest portion of the total operational cost.

The alternatives are evaluated according to internal rate of return method, which shows the profit of the investment. For the internal rate of return calculations, differences between investment, operational and amortization cost of the alternatives are used. The amortization life is considered as 20

Table 4

Total investment and operational cost of the heating system alternatives for each scenario

\begin{tabular}{lllll}
\hline Alternative no. & $\begin{array}{l}\text { Total investment } \\
\text { cost (US\$) }\end{array}$ & \multicolumn{2}{l}{ Annual operational cost (US\$/year) } \\
\cline { 3 - 5 } \cline { 3 - 4 } & Scenario 1 & Scenario 2 & Scenario 3 \\
\hline $\begin{array}{l}\text { 1 (heat pump } \\
\text { district }\end{array}$ & 3040125 & 127843 & 171889 & 239556 \\
$\begin{array}{l}\text { heating } \\
\text { system) }\end{array}$ & & & & \\
$2 \begin{array}{l}\text { (fuel boiler } \\
\text { district } \\
\text { heating } \\
\text { system) }\end{array}$ & 1068301 & 358664 & 482234 & 672076 \\
\end{tabular}


Table 5

Operational cost of the heat pump and fuel boiler district heating system

\begin{tabular}{|c|c|c|c|c|}
\hline \multirow[t]{3}{*}{ Operational cost components } & \multicolumn{4}{|c|}{ Operational cost } \\
\hline & \multicolumn{2}{|c|}{$\begin{array}{l}\text { Heat pump district } \\
\text { heating system }\end{array}$} & \multicolumn{2}{|c|}{$\begin{array}{l}\text { Fuel boiler distric } \\
\text { heating system }\end{array}$} \\
\hline & US\$ & $\%$ & US\$ & $\%$ \\
\hline \multicolumn{5}{|l|}{ Electricity } \\
\hline Heat pumps & 85837 & 67.1 & - & - \\
\hline $\begin{array}{l}\text { Circulation } \\
\text { and well pumps }\end{array}$ & 21966 & 17.2 & 11710 & 3.3 \\
\hline Fuel oil & - & - & 327780 & 91.4 \\
\hline Personnel & 9900 & 7.7 & 9900 & 2.8 \\
\hline Water & 1120 & 0.9 & 1119 & 0.3 \\
\hline Inhibitor & 573 & 0.4 & - & - \\
\hline Other chemicals & 292 & 0.2 & - & - \\
\hline Maintenance & 8155 & 6.4 & 8155 & 2.3 \\
\hline Total & 127843 & 100.0 & 358664 & 100.0 \\
\hline
\end{tabular}

Table 6

Summary of cost comparison of the investment of the heating system alternatives

\begin{tabular}{lll}
\hline Scenario no. & \multicolumn{2}{l}{ Alternatives 1 and 2} \\
\cline { 2 - 3 } & Cash flow (US\$) & Internal rate of return (\%) \\
\hline 1 & 672772 & 3.02 \\
2 & 2263252 & 8.73 \\
3 & 4706752 & 17.10 \\
\hline
\end{tabular}

years. In internal rate of return calculation, annual operational costs of the systems are assumed constant during the 20-year and difference between the operational costs is considered as profit. Cash flow is the difference between annual profit and amortization cost of the systems. For the Scenario 1, which is similar with the real case of the campus, Alternative 1 and 2 are compared for amortization cost and the cash flow at the end of 20 -year. The cash flow of the Alternative 1 (heat pump district heating system) is 672,772 US $\$$ depending on the Alternative 2 (fuel boiler district heating system). Internal rate of return is calculated as $3.02 \%$ for Scenario 1 . The results of cost comparison of the investment are summarized in Table 6 [5].

\section{Conclusions}

The main purpose of this study is to investigate the possibility of a district heating system for İzmir Institute of Technology campus using existing geothermal resource.

Study considers two types of district heating system types;

1. Heat pump heating system (using a renewable energy source, geothermal energy),

2. Fuel boiler heating system (using a conventional energy source, fuel oil).

Each heating system is simulated using hourly outdoor temperature data. For these heating simulations, the main control parameter is the indoor temperature of the buildings. Mathematical models are derived using Matlab [3] and EES [4] programs.

Heat pump district heating system has two options depending on resource temperature, heat pump only and heat pump assisted. Heat pump only layout is selected for the campus heating system because it exhibits better performance than heat pump assisted at geothermal fluid temperatures below than $40{ }^{\circ} \mathrm{C}$. Various heating regime alternatives have been studied for heat pump district heating system for the various condenser outlet temperature and geothermal fluid flow rate. Consequently, the heating regime with $35^{\circ} \mathrm{C}$ condenser inlet and $45^{\circ} \mathrm{C}$ condenser outlet temperature with $120 \mathrm{~kg} / \mathrm{s}$ geothermal fluid flow rate considered to be the best option. Four separate heat pump units of the same capacity are considered because of the improved performance, reliability and operational flexibility. Each heat pump is fed by each production well and heat pumps are operated depending on outdoor temperature. For each heat pump unit, one heat exchanger is employed.

Existing boiler heating systems of the campus are operated manually by technicians. Technicians decide the boiler set temperature according to their experiences and each heat centre of the campus is operated in a different way. In the study, fuel boiler district heating system was run for various boiler set temperatures and the results showed that fuel consumption of the boiler changes drastically with changing boiler set temperature. Boiler set temperatures have been recommended by Dağsöz [10] is the best alternative with least fuel consumption and best indoor temperature around $20^{\circ} \mathrm{C}$. Therefore, energy management system implementation is recommended for the campus. General operational regulations should be formed to improve efficiency and achieve energy cost savings. Each heat centre should be operated according to these regulations simultaneously. The combustion products of the existing heating system should be analysed periodically. Energy consumption and energy saving measures of the campus should be observed regularly.

Economic analysis has also been done for two heating alternatives. For the Scenario 1, which is similar to the existing heating system of the campus, the heat pump district heating system has $3.02 \%$ profit at the end of the 20 -year period comparing with fuel boiler district heating system. According to the results heat pump district heating system is more attractive than fuel boiler district heating system.

Although only heating requirements considered in the study, each building is also equipped with cooling system. Thus, considered heat pump district heating system can be used for cooling requirements as well, for boiler heating systems, chillers should be installed to the system. Thus, the investment cost of the boiler heating system increases. Therefore, the heat pump district heating system could be more attractive than fuel boiler district heating system if cooling requirements of the buildings are considered.

Heat pump district heating system is designed according to 0.67 heat load factor. When outdoor temperature is below $5{ }^{\circ} \mathrm{C}$, system cannot maintain required indoor temperature. To 
compensate this, existing boilers can be used as peaking plant.

\section{References}

[1] T. Karlsson, Geothermal district heating the Iceland Experience. UNU Geothermal Training Programme, Iceland, Report 1982-4.

[2] R. Harrison, N.D. Mortimer, O.B. Smarason, Geothermal Heating a Handbook of Engineering Economics, 1990558 pp.

[3] The MathWorks. Matlab program, The MathWorks internet website, http://www.mathworks.com/products/, 2004.

[4] F-Chart Software. EES Engineering Equation Solver, F-Chart Software internet website, http://www.fchart.com/ees/ees.shtml, 2004.
[5] N. Yildırım, District Heating System of IZTECH (Izmir Institute of Technology) Campus and its Integration to the Existing System, İzmir Institute of Technology, M.Sc., Thesis, 2003, 158 pp.

[6] A.B. Erdoğmuş, Economic Assessment of Balçova-Narlıdere Geothermal District Heating System, M.Sc., Thesis, İzmir Institute of Technology, 2003, 179 pp.

[7] A.C. Gürses, Design criteria of geothermal district heating systems, in: Technical Publications of Chamber of Mechanical Engineers, No. 27 (2001) 117-127 (in Turkish).

[8] M.E. Emeish, Simulation of Heating Systems in Jordanian Buildings, University of Iceland, M.Sc., Thesis, UNU Geothermal Training Programme, Iceland, 2001 Report, $91 \mathrm{pp}$.

[9] TRANE Air Conditioning Inc., personal communication, 2003.

[10] A.K. Dağsöz, Chapter 19, Technical Publication of Demirdokum Inc., No. 6 (1998) 268-281 (in Turkish). 